\title{
Genetic variation in the myeloperoxidase gene and cognitive impairment in Multiple Sclerosis
} I Manna ${ }^{1}$, P Valentino ${ }^{2}$, A La Russa ${ }^{1}$, F Condino ${ }^{1}$, R Nisticò ${ }^{2}$, M Liguori ${ }^{1}$, A Clodomiro ${ }^{2}$, V Andreoli ${ }^{1}$, D Pirritano ${ }^{2}$, R Cittadella ${ }^{1}$ and A Quattrone*1,2

\author{
Address: ${ }^{1}$ Institute of Neurological Science, National Research Council, Cosenza, Italy and ${ }^{2}$ Department of Medical Sciences, Institute of \\ Neurology, University "Magna Graecia", Catanzaro, Italy \\ Email: I Manna - i.manna@isn.cnr.it; P Valentino - p.valentino@isn.cnr.it; A La Russa - a.larussa@isn.cnr.it; F Condino - f.condino@isn.cnr.it; \\ R Nisticò - a.quattrone@isn.cnr.it; M Liguori - m.liguori@isn.cnr.it; A Clodomiro - a.quattrone@isn.cnr.it; V Andreoli - v.andreoli@isn.cnr.it; \\ D Pirritano - a.quattrone@isn.cnr.it; R Cittadella - r.cittadella@isn.cnr.it; A Quattrone* - a.quattrone@isn.cnr.it \\ * Corresponding author
}

Published: 27 February 2006

Journal of Negative Results in BioMedicine2006, 5:3 doi:10.1 I86/1477-575I-5-3

This article is available from: http://www.jnrbm.com/content/5/I/3

(c) 2006Manna et al; licensee BioMed Central Ltd.

This is an Open Access article distributed under the terms of the Creative Commons Attribution License (http://creativecommons.org/licenses/by/2.0), which permits unrestricted use, distribution, and reproduction in any medium, provided the original work is properly cited.
Received: 10 November 2005

Accepted: 27 February 2006

\begin{abstract}
There is evidence that multiple sclerosis (MS) may associated with cognitive impairment in 25 to $40 \%$ of cases. The gene encoding myeloperoxidase (MPO) is involved in molecular pathways leading to $\beta$-amyloid deposition. We investigated a functional biallelic $(\mathrm{G} / \mathrm{A})$ polymorphism in the promoter region (-463) of the MPO gene in 465 patients affected by MS, divided into 204 cognitively normal and $26 \mathrm{I}$ impaired. We did not find significant differences in allele or genotype distributions between impaired and preserved MS patients. Our findings suggest that MPO polymorphism is not a risk factor for cognitive impairment in MS.
\end{abstract}

\section{Findings}

Multiple sclerosis (MS) is a chronic inflammatory disease of the central nervous system (CNS), characterised by primary demyelination with relative axonal sparing and by a clinical course that varies from relapsing remitting (RR) to chronic progressive (CP). Cognitive dysfunction occurs in $25-40 \%$ of patients with MS, and it is often a major cause of disability in patients with the disease [1]. Although the pathogenesis of MS is not fully understood the role of genetic factors is firmly established [2]. Such a genetic factor might be better identified through association studies which look for an increased frequency of a particular genetic marker or allele among the affected individuals as compared to unaffected individuals. The myeloperoxidase (MPO) gene encodes for an enzyme that catalyses a reaction between hydrogen peroxide and chloride to generate hypochlorous acid, a potent oxidant leading to oxidising conditions that are known to increase $\beta$-amiloid protein (A $\beta$ ) deposition [3]. The MPO gene, at 17q23.1, contains a functionally important $\mathrm{G}$ to A base substitution polymorphism, 463 bases upstream from the transcription start site, which has been found to cause a decreased transcriptional activity in cellular transfection assays due to the destruction of an SP1 binding site [4]. A few studies have investigated the $-463 \mathrm{G} / \mathrm{A} \mathrm{MPO}$ promoter polymorphism in MS. Nagra and co-workers [5] found an overrepresentation of the GG genotype in women with early onset MS. Two subsequent studies found no association between the MPO promoter polymorphism and MS [6,7]. In a recent work Zakrewska-Pniewska and co-workers analysed the relationship between APOE and MPO genes' polymorphisms and MS, and they found that the genotype GG of MPO was related to more pronounced brain atrophy [8]. Owing to the protein product of the MPO 
Table I: Genotypes and allele frequencies of the MPO polymorphism

\begin{tabular}{|c|c|c|c|c|c|}
\hline & Preserved $N=204$ & Impaired $N=26$ I & P-value & $\mathrm{OR}^{*}$ & $95 \% \mathrm{Cl}^{*}$ \\
\hline \multicolumn{6}{|c|}{ Genotype frequency } \\
\hline AA & $12(5.9 \%)$ & $16(6.1 \%)$ & 0.649 & 0.956 & $0.435-2.102$ \\
\hline AG & $70(34.3 \%)$ & 79 (30.3\%) & & 0.852 & $0.569-1.273$ \\
\hline GG & $122(59.8 \%)$ & $166(63.6 \%)$ & & 1.0 & \\
\hline \multicolumn{6}{|c|}{ Allele frequency } \\
\hline$A$ & $94(23.0 \%)$ & III (21.3\%) & 0.517 & 0.909 & $0.665-1.244$ \\
\hline G & $314(77.0 \%)$ & $41 \mathrm{I}(78.7 \%)$ & & 1.0 & \\
\hline
\end{tabular}

*Odds Ratios and $\mathrm{Cl}$ were estimated using logistic regression adjusted for age and sex.

gene being involved in $\mathrm{AD}$ pathology, possibly through oxidation of $A \beta$ or $A p o E$, promoting their aggregation into insoluble complexes, or directly through oxidationinduced damage to associated neurons [9], there is biologic evidence implicating MPO in the cognitive decline in patients with MS, but no definite data are currently available on the possible role of MPO polymorphism in the development of cognitive decline in MS. This study was mainly designed to investigate whether some clinical and individual variables and the occurrence of the $-463 \mathrm{G} /$ A promoter polymorphism of the MPO gene may be associated with cognitive impairment in patients with MS. The sample included in this study consisted of 465 patients affected by MS data on our patients were reported in greater detail elsewhere [10]. Informed consent to perform molecular genetic studies was obtained from all patients.

Genomic DNA was prepared from leukocytes harvested from whole blood using standard methods. The PCRRFLP based assay was used to characterise the wild-type (G) and variant (A) MPO alleles at position -463 [11]. Statistical analyses were performed with Statistical Package for Social Sciences software SPSS (version 12.0, Chicago, IL, USA) for Windows '98/'00. In our sample of consecutive patients affected by MS, we found the cognitive deterioration was present at different degrees of severity in the majority of the patients. More in detail, two-hundred and four patients $(44 \%)$ were found to be cognitively preserved by the neuropsychological evaluation, whereas 261 (56\%) failed at least one test and were therefore considered cognitively impaired. The cognitively impaired group differed from the preserved group in the following characteristics: a longer disease duration, a high EDSS score, a greater proportion of individuals with secondary progressive form and a lower education. No difference was found in the number of failed neuropsychological test among subjects with different polymorphic variants $(\mathrm{p}=0.805$; Kruskal-Wallis test). No significant difference was found in the genotypic $\left(\mathrm{p}=0.649\right.$; Pearson $\chi^{2}$-test $)$ or allelic distribution ( $\mathrm{p}=0.517$; Pearson $\chi^{2}$-test) of the $-463 \mathrm{G} / \mathrm{A}$ promoter polymorphism of the MPO gene between preserved and impaired subjects (Table). Furthermore, considering a power of $80 \%$ and a significance level of 0.05 , the power calculation for the A allele shows that the ORs detectable as significant resulted lower than 0.618 and higher than 1.527. These results suggest that the $-463 \mathrm{G} / \mathrm{A}$ promoter polymorphism of the MPO gene does not confer a risk of cognitive impairment in patients with MS.

\section{List of abbreviations}

CI confidence interval

\section{Authors' contributions}

IM, PV, A La R, partecipated in the study design, carried out the data collection and analysed the results. FC performed the statistical analysis. RN, ML, AC, VA, DP and RC partecipated to acquisition of data. AQ conceived the study and partecipated in its design and coordination and drafted the manuscript.

\section{References}

I. Rao SM, Leo GJ, Bernardin L, Unverzagt F: Cognitive dysfunction in multiple sclerosis. I. Frequency, patterns, and prediction. Neurology I991, 41:685-69|.

2. Hogancamp WE, Rodriguez M, Weinshenker BG: The epidemiology of Multiple Sclerosis. Mayo Clin Proc 1997, 72:87I-878.

3. Smith MA, Hirai K, Hsiao K, Pappolla MA, Harris PL, Siedlak SL, Tabaton M, Perry G: Amyloid-beta deposition in Alzheimer transgenic mice is associated with oxidative stress. J Neurochem 1998, 70(5):2212-5.

4. Piedrafita FJ, Molander RB, Vansant G, Orlova EA, Pfahl M, Reynolds WF: An Alu element in the Myeloperoxidase promoter contains a composite SPI-tyroid hormone-retinoic acid response element. J Biol Chem 1996, 27 I: | 44 I2- | 4420.

5. Nagra RM, Becher B, Tourtellotte WW, Antel JP, Gold D, Paladino T, Smith RA, Nelson JR, Reynolds WF: Immunohistochemical and genetic evidence of Myeloperoxidase involvement in Multiple Sclerosis. J Neuroimmunol 1997, 78:97-107.

6. Kantarci OH, Atkinson EJ, Hebrink DD, McMurray CT, Weinshenker BG: Association of a myeloperoxidase promoter polymorphism with multiple sclerosis. J Neuroimmunol 2000, I05(2): 189-94.

7. Nelissen I, Fiten P, Vandenbroeck K, Hillert J, Olsson T, Marrosu MG, Opdenakker G: PECAMI, MPO and PRKARIA at chromosome $17 q 21-q 24$ and susceptibility for multiple sclerosis in Sweden and Sardinia. Neuroimmunol 2000, I08(I-2): I53-9.

8. Zakrzewska-Pniewska B, Styczynska M, Podlecka A, Samocka R, Peplonska B, Barcikowska M, Kwiecinski H: Association of apolipoprotein $E$ and myeloperoxidase genotypes to clinical course of familial and sporadic multiple sclerosis. Mult Scler 2004, I0(3):266-7I.

9. Reynolds WF, Rhees J, Maciejewski D, Paladino T, Sieburg H, Maki RA, Masliah E: Myeloperoxidase polymorphism is associated with gender specific risk for Alzheimer's disease. Expe Neurol 1999, 78:97-107. 
10. Savettieri G, Messina D, Andreoli V, Bonavita S, Caltagirone C, Cittadella R, Farina D, Fazio MC, Girlanda P, Le Pira F, Liguori M, Lugaresi A, Nocentini U, Reggio A, Salemi G, Tedeschi G, Trojano M, Valentino $P$, Quattrone A: Gender-related effect of clinical and genetic variables on the cognitive impairment in multiple sclerosis. J Neurol 2004, 25 I ( I 0): I 208- I4.

II. Zappia M, Manna I, Serra P, Cittadella R, Andreoli V, La Russa A, Annesi F, Spadafora P, Romeo N, Nicoletti G, Messina D, Gambardella $A$, Quattrone $A$ : Increased risk for Alzheimer disease with the interaction of MPO and A2M polymorphisms. Arch Neurol 2004, 6 I (3):34 I-4.

Publish with Bio Med Central and every scientist can read your work free of charge

"BioMed Central will be the most significant development for disseminating the results of biomedical research in our lifetime. " Sir Paul Nurse, Cancer Research UK

Your research papers will be:

- available free of charge to the entire biomedical community

- peer reviewed and published immediately upon acceptance

- cited in PubMed and archived on PubMed Central

- yours - you keep the copyright

Submit your manuscript here:

http://www.biomedcentral.com/info/publishing_adv.asp 